\title{
PENGARUH PENGGUNAAN MULTIMEDIA PEMBELAJARAN INTERAKTIF DAN MOTIVASI BELAJAR TERHADAP HASIL BELAJAR TEKNOLOGI INFORMASI DAN KOMUNIKASI (TIK) SISWA SMA NEGERI 1 SUNGGAL
}

\author{
Kristina Pardede ${ }^{1}$, Efendi Napitupulu ${ }^{2}$ \\ SMA Negeri 1 Sunggal, Teknologi Pendidikan Pascasarjana Universitas Negeri Medan \\ xtina0974@gmail.com ${ }^{1}$
}

\begin{abstract}
Abstrak: Penelitian ini bertujuan untuk: (1) mengetahui pengaruh penggunaan multimedia pembelajaran interaktif Drill and Practice dibandingkan dengan Tutorial terhadap tingkat pengetahuan operasional komputer siswa, (2) mengetahui pengaruh motivasi belajar tinggi dan motivasi belajar rendah terhadap tingkat pengetahuan operasional komputer siswa mata pelajaran Teknologi Informasi dan Komunikasi, dan (3) mengetahui interaksi antara penggunaan multimedia pembelajaran interaktif Drill and Practice dan Tutorial dan motivasi belajar siswa dalam mempengaruhi tingkat pengetahuan operasional komputer siswa. Metode penelitian adalah quasi eksperimen. Hasil penelitian menunjukkan: (1) hasil belajar Teknologi Informasi dan Komunikasi siswa yang dibelajarkan dengan menggunakan multimedia pembelajaran latihan dan praktik lebih tinggi daripada hasil belajar Teknologi Informasi dan Komunikasi siswa yang dibelajarkan dengan menggunakan multimedia pembelajaran tutorial, (2) hasil belajar Teknologi Informasi dan Komunikasi siswa yang memiliki motivasi belajar tinggi lebih tinggi daripada hasil belajar Teknologi Informasi dan Komunikasi siswa yang memiliki motivasi belajar rendah, dan (3) terdapat interaksi antara penggunaan multimedia pembelajaran interaktif Drill and Practice dan Tutorial dan motivasi belajar siswa tingkat pengetahuan operasional komputer mata pelajaran Teknologi Informasi dan Komunikasi.
\end{abstract}

Kata kunci: Multimedia Pembelajaran, Motivasi Belajar, Tingkat Pengetahuan, Operasional Komputer.

\begin{abstract}
This study aimed to: (1) the effect of the use of multimedia interactive learning Drill and Practice as compared to the tutorial on the level of operational knowledge of computer students, (2) the effect of learning motivation high and low learning motivation on the level of operational knowledge of student computers subjects Technology information and Communication, and (3) the interaction between the use of multimedia interactive learning and a Drill and Practice tutorial and student motivation in influencing the level of operational knowledge of student computers. The research method was quasi-experimental. The results showed: (1) the learning outcomes of Information Technology and Communication students that learned by using learning multimedia exercises and practices are higher than the learning outcomes of Information Technology and Communication students that learned by using learning multimedia tutorial, (2) the learning outcomes of Information Technology and Communication students who have learning motivation high is higher than the learning outcomes of Information Technology and Communication students who have low learning motivation, and (3) there is interaction between the use of multimedia interactive learning Drill and Practice and Tutorial and students' motivation level operational knowledge of computer subjects Information Technology and Communication.
\end{abstract}

Keywords: Multimedia Learning, Motivation, Knowledge Level, Computer Operations.

\section{PENDAHULUAN}

Guru merupakan salah satu faktor penting dalam keberhasilan siswanya. Guru dituntut untuk bisa kreatif dalam menyampaikan materi pelajaran kepada dengan menggunakan media yang menarik bagi siswa yang menumbuhkan rasa ingin tau dan tertarik pada materi yang diajarkan kepada siswa. Usaha ini harus dilakukan dalam rangka meningkatkan hasil belajar. Salah satu caranya dengan menggunakan strategi pembelajaran yang bervariasi dan menarik dalam 
menyampaikan materi pelajaran. Menggabungkan suatu metode dengan metode lainya sehingga didapatkan suatu metode yang tepat sesuai dengan karakteristik siswa dan strategi pembelajaran yang digunakan guru hendaknya dapat diterima siswa yang memiliki gaya belajar yang berbeda beda khusunya dalam mempelajari mata pelajaran TIK di kelas.

Ciri - ciri perkembangan IPTEK dalam era teknologi informasi dan komunikasi yaitu; (1) daya muat untuk mengumpulkan, menyiapkan, manipulasikan, dan menyajikan informasi meningkat; (2) kecepatan penyajian informasi meningkat; (3) miniaturisasi perangkat keras; (4) keragaman pilihan informasi; (5) menurunnya biaya perolehan informasi; (6) mudahnya penggunaan produk teknologi informasi; (7) distribusi informasi yang semakin cepat dan luas; (8) pemecahan masalah yang lebih baik dan dibuatnya prediksi masa depan yang lebih tepat (Miarso, 2004:664-665). Dalam era teknologi informasi dan komunikasi seperti ini, kemampuan masyarakat dalam memanfaatkan pengetahuannya untuk meningkatkan produktivitas menjadi vital.

Media merupakan salah satu komponen utama dalam pembelajaran selain tujuan, materi, metode dan evaluasi, maka sudah seharusnya dalam pembelajaran guru menggunakan media pembelajaran yang disajikan dengan menggunakan media elektronik yang didesain untuk kepentingan belajar mengajar.

Media diharapkan memberikan ransangan pada aktivitas daya indra secara bervariasi sehingga memungkinkan materi yang disajikan lebih mudah dipahami dan dipertahankan dalam ingatan. Pemanfaatan media dapat memberikan berbagai pengalaman yang memungkinkan keterlibatan aktif siswa dalam pembelajaran. Pemanfaatan media yang sesuai dengan karakteristik siswa dapat menumbuh kembangkan daya pikir dan kreativitas siswa serta memungkinkan terjadinya belajar sendiri. Pada akhirnya, pemanfaatan media memungkinkan tercapainya efektivitas pembelajaran mandiri dan meningkatkan tingkat pengetahuan tentang oprasional komputer.

Menurut Dimyati dan Mudjiono (2006:34) menyatakan bahwa motivasi dipandang sebagai dorongan mental yang menggerakkan, menyalurkan, dan mengarahkan sikap dan perilaku individu belajar. Jadi motivasi dalam belajar sangatlah penting sehingga tercapai tingkat pengetahuan akan mengoperasikan komputer yang baik. Motivasi siswa harus mendapat perhatian sebelum memulai pelajaran agar guru dapat menentukan strategi pembelajaran yang diterapkan.

Hilgard (1962) : "belajar adalah proses dimana suatu perilaku muncul atau berubah karena adanya respons terhadap sesuatu situasi”. Miarso (2004:550) mengemukakan bahwa: "Aliran behaviorisme memandang terjadinya belajar sebagai akibat adanya pengkondisian lingkungan diikuti dengan adanya penguatan (reinforcement), serta aliran Gestalt memandang terjadinya belajar karena adanya usaha bertujuan, eksploratif, imajinatif, dan kreatif, sedangkan aliran kontruktivisme memandang terjadinya belajar karna adanya ketidaksesuaian antara struktur kognitif seseorang dengan informasi baru yang dihadapinya dan menyebabkan ketidak seimbangan (disequilibrium) dan struktur kognitifnya". Belajarmerupakan kegiatan atau suatu perilaku yang muncul atau perubahan perilaku, kebiasaan serta sikap yang baru dan relatif menetap karena pengalaman atau penguatan (reinforcement), yang dilakukan individu untuk memperoleh perubahan perilaku baru secara keseluruhan, sebagai hasil dari individu itu sendiri dalam berinteraksi dengan lingkungannya dan dimanifestasikan sebagai pola-pola respons yang baru berbentuk keterampilan, sikap, kebiasaan, pengetahuan dan kecakapan.

Hamalik (2006:155), memberikan gambaran bahwa hasil belajar yang diperoleh dapat diukur melalui kemajuan yang diperoleh siswa setelah belajar dengan sungguh-sungguh. Hasil belajar adalah tujuan akhir dilaksanakannya kegiatan pembelajaran serta kemampuan yang dimiliki siswa setelah menerima pengalaman belajar dan perubahan perilaku secara positif yang relatif permanen pada diri orang yang belajar, perubahan tersebut dari segi kemampuan berpikir, kemampuan memecahkan masalah serta kawasan kognitif, afektif dan psikomotor dan dapat 
diukur melalui tingkat keberhasilan (prestasi) siswa, kemajuan yang diperoleh siswa setelah belajar dengan sungguhsungguh dapat diukur dengan melakukan tes dan pengukuran dalam bentuk test dan non tes, sebagai alat pengumpul data disebut dengan instrumen penilaian hasil belajar. Komputer berasal dari kata "to compute" yang artinya menghitung. Dengan memanfaatkan komputer dalam proses pembelajaran atau yang sering disebut dengan Pembelajaran Berbantukan Komputer (PBK) dibandingkan dengan pengajaran tradisional maka akan banyak perbedaan penting yang terlihat (Capper, and Copple:1985).

\section{Penggunaan}

Pembelajaran

berbantukan komputer secara perorangan memungkinkan untuk mengawasi pemahaman siswa secara tetap dan respons yang diberikan oleh PBK berdasarkan kebutuhan individu siswa. Siswa yang berposisi sebagai pengguna komputer atau disebut dengan End-User Computing yang disingkat dengan (EUC) adalah pengguna konputer secara langsung oleh seseorang untuk menyelesaikan masalah yang memerlukan pemecahan masalah berbasis komputer (computer based solution) dengan cepat (Horrison dan Rainer dalam (Isdhe diakses januari 2011). Tingkat pengetahuan operasional komputer dalam penelitian ini pada siswa SMA yaitu pengetahuan pemanfaatan komputer yang meliputi pengetahuan dasar mengenai jenis dan fungsi dari berbagai perangkat keras komputer serta perintah dasar pengolahan dan menejeman file, pengetahuan dan pemanfaatan aplikasi perkantoran (office aplication) meliputi pengolahan kata (microsoft word) dan pengolah angka (worksheet) serta pengelolan dan pemanfaatan aplikasi internet. Russell (2011:7) "Media merupakan bentuk jamak dari perantara (medium), yang menjadi sarana komunikasi. Hamid (2009:55), media pembelajaran adalah komponen strategi penyampaian yang dapat dimuati pesan yang akan disampaikan kepada pebelajar, apakah itu orang, alat atau bahan.
Heinich, Molenda, dan Russel (Instructional Media, 1990) diungkapkan bahwa media "is a channel of comunication. Derived from the latin word for "between", the term refers "to anything that carries information between a source and receiver". Heinich (1989: 334) Computer systems can deliver instruction directly to students by allowing them to interact with lessons programmed into the system; this is referred to as ComputerAssisted Instruction (CAI). The various utilization possibilities can best bediscussed in terms of the various instructionsl modes that the computer can facilitate most effectively: drill and practice, tutorial, gaming, simulation, discovery, and problem solving. Smaldino (2005: 148) "The hearth of an interactive media system is the computer, which provides the intelegence and interavtivity required. The computer can command the system to present audio or vidio information, wait for learner's response, and branch to the appropriate ponit in the instructional-program from that response".

Smaldino

(2005:

mengemukakan, "interactive media is a powerfull, practical method for individualizing and personalizing instruction". Komputer berperan sebagai manajer dalam proses pembelajaran yang dikenal dengan nama Computer-Managed Instruction (CMI). Ada pula peran komputer sebagai peran tambahan dalm belajar; pemanfaatannya meliputi penyajian informasi isi materi pelajaran, latihan, atau kedua-duanya. Multimedia interaktif merupakan alat atau sarana ataupun mediaganda (multiple media), berupa teks, audio, grafik, animasi, suara teks, gambar, dan vidio, yang penayangannya bergerak dinamis berubah dengan perlahan yang memerlukan interaksi siswa serta diikutsertakan lebih besar dalam aktivitas pembelajaran semuanya dapat disatukan dalam penyampian materi, metode yang dirancang secara sistematis dan menarik untuk mencapai kompetensi/subkompetensi mata pelajaran yang diharapkan dengan 
menggunakan komputer dan siswa akan lebih mudah memahami konsep - konsep yang bersifat abstrak serta dengan bantuan seminimal mungkin dari guru atau orang lain, dan belajar sesuai dengan kecepatan belajar masing - masing (self-pacing).

Geisert dan Futrell (Rusman, 2009) menyatakan bahwa: "Drill and practice programs, help learners refine or enhance. The normally complement classroom instructional by rainforcing skills already learned. In such programs the usual job the computer is repetitive and follows and district patter. Explain that the routine is commonly guite simple." Karakteristik pembelajaran interaktif latihan dan praktik adalah: (1) materi telah disampaikan pada pertemuan sebelumnya atau akan memberikan selanjutnya; (2) bersifat pretest dengan fungsi diagnostik kemampuan pemahaman dan kecepatan belajar siswa; (3) tanpa banyak uraian dan sederhana; (4) bersifat penerapan dan kesimpulan; (5) materi yang sifatnya dasar atau pra-syarat dalam mempelajari materi selanjutnya; dan (6) menekankan pada aspek kognitif. Latihan dan praktik pada dasarnya merupakan salah satu pembelajaran yang bertujuan memberikan pengalaman bekerja yang kongkret melalui penciptaan tiruantiruan bentuk penglaman yang mendekati suasana yang sebenarnya. Hal ini juga merupakan salah satu dari karakteristik latihan dan praktik dalam pembelajaran berbasis komputer yang memberikan pengalaman belajar yang lebih kongkrit melalui penyediaan latihan-latihan soal yang bertujuan untuk menguji performance dan kemampuan siswa melalui kecepatan penyelesaian soal-soal latihan yang memberikan melalui program yang disediakan.

Heinich (1985:315) menjelaskan pembelajaran tutorial adalah: "Programmed tutoring (also referred to as structured tutoring) is one-to one method of instruction in which the decisions to be made by the tutor are "programmed" in advance by means of carefully structured printed instructions." Hackbarth (1996) tutorial adalah pengenalan dan penjelasan mengenai konsep-konsep dan keterampilanketerampilan yang akan diperaktekkan. Seperti bahan-bahan pembelajaran terprogram, dan menyakinkan kerangka informasi dan pertanyaan-pertanyaan. Rusman (2009) media interaktif model tutorial berbantuan komputer adalah sebagai tutor yang berorientasi pada upaya dalam membangun perilaku siswa melalui penggunaan komputer. Adapun karakteristik media pembelajaran interaktif tutorial adalah sebagai: (1) informasi baru; (2) bersifat konsep; (3) luas dan mendalam; (4) memerlukan kontrol dan mastery learning; (5) berhubungan antara bagian pokok materi yang satu dan lainnya; (6) memungkinkan dipelajari secara berulang; (7) memiliki pola berpikir dan arah pembelajaran bercabang (branching); (8) membutuhkan kontrol waktu dalam setiap segmen materi atau mastery learning secara keseluruhan; dan (9) menekankan pada pengoptimalan pencapaian aspek kognitif.

Secara etimologi perkataan motivasi adalah berasal bahasa latin "movere" yang artinya dorongan atau yang menggerakkan. Bahasa Inggris motivasi (motivation) berasal dari kata motie yang artinya menggerakkan. Dalam kamus bahasa Indonesia, kata motif diartikan sebagai daya upaya untuk mendorong seseorang untuk melakukan sesuatu.

Paul\&Dale (2002:5) "Motivation is the process whereby goal-directed activity is instigated and sustained". Paul\&Dale (2002:5) "Motivation is a process rather than a product". Menurut Sardiman (2011:73) motivasi belajar dapat dikatakan sebagai keseluruhan daya penggerak dari dalam dan di dalam diri siswa yang menimbulkan kegiatan belajar, yang menjamin kegiatan kelangsungan dari kegiatan belajar dan yang memberikan arah pada kegiatan belajar, sehingga tujuan yang akan dikehendaki oleh subjek belajar itu dapat dicapai. Winkel W, (1983) menyatakan motivasi belajar adalah sesuatu yang menimbulkan semangat atau dorongan belajar, dimana kuat lemahnya motivasi 
tersebut ikut menentukan tinggi rendahnya prestasi belajarnya. Amirullah dan Hanafi (2002) mengemukakan motivasi belajar dapat difenisikan sebagai kondisi yang berpengaruh membangkitkan, mengarahkan, dan memelihara perilaku yang berhubungan dengan lingkungan belajar.

Sardiman (2007:75) motivasi belajar dapat juga diartikan sebagai serangkaian usaha untuk menyediakan kondisi-kondisi tertentu, sehingga seseorang mau dan ingin melakukan sesuatu, dan bila ia tidak suka, maka akan berusaha untuk meniadakan atau mengelak perasaan tidak suka. Motivasi belajar adalah: serangkaian usaha untuk menyediakan kondisi-kondisi tertentu, dorongan (tenaga) atau faktor yang dapat membangkitkan, mempengaruhi, menimbulkan, mengarahkan, dan mengorganisasikan serta memelihara tingkah laku manusia yang berhubungan dengan lingkungan belajar dalam memenuhi cita-cita, aspirasi siswa, semangat belajar yang akan membuat kepuasan siswa dengan memberikan angka, hadiah, ulangan, hasil belajar serta pujian yang mempengaruhi siswa dalam meningkatkan kemauan dan semangat belajar dalam mencapai tujuan pembelajaran.

Permasalahan yang diangkat dalam penelitian ini adalah "Bagaimana pengaruh penggunaan mlutimedia pembelajaran interaktif berbasis komputer dan motivasi belajar siswa terhadap tingkat pengetahuan operasional komputer siswa?"

Rumusan masalah penelitian adalah: (1) Apakah Tingkat Pengetahuan Operasional Komputer pada siswa yang diajar dengan Menggunakan Multimedia Interaktif Drill and Practice lebih tinggi dari siswa yang diajar dengan menggunakan Multimedia Interaktif Tutorial, (2) Apakah siswa yang memiliki Motivasi Belajar Tinggi akan memiliki Tingkat Pengetahuan Operasional Komputer lebih tinggi dari siswa yang memiliki Motivasi Belajar Rendah ; dan (3) Apakah ada Interaksi Antara Penggunaan Multimedia Pembelajaran
Interaktif dan Motivasi Belajar Terhadap Tingkat Pengetahuan Operasional Komputer Siswa.

\section{METODE PENELITIAN}

Pelaksanaan penelitian ini dilaksanakan di SMA Negeri 1 Sunggal dan kelas XI semester ganjil tahun ajaran 2014/ 2015. Pelaksanaan direncanakan akan dimulai pada bulan September sampai Desember. Dengan rincian pembagian angket dan tes hasil belajar. Proses pembelajaran dilaksanakan di kelas dan disesuaikan dengan kalender pendidikan dan jadwal pelajaran yang berlaku di sekolah yang akan dilaksanakan penelitian. Populasi dalam penelitian ini adalah siswa kelas X SMA N.1 Sunggal yang terdiri dari 8 kelas, dengan rincian 4 kelas IPA dan 4 kelas IPS dengan jumlah keseluruhan adalah 305 siswa. Penentuan karakteristik siswa kelas tersebut tidak dikelompokkkan atas ranking dan pengelompokkan kelas unggulan tetapi dilakukan secara acak saja sewaktu penempatan siswa dalam kelompok masing- masing.

Teknik pengambilan sampel dalam penelitian ini dengan cluster random sampling. Teknik ini dipilih karena yang di samping dari populasi adalah jumlah kelas bukan jumlah siswa dalam populasi. Sampel yang diambil terdiri dari dua kelompok yaitu, satu kelompok kelas dilakukan pembelajaran menggunakan strategi pembelajaran Drill and Practice, yang dilakukan di SMA Negeri 1 Sunggal pada kelas XI IPS 1 yang berjumlah 32 orang dan satu kelas lainnya dilakukan strategi pembelajaran menggunakan multimedia interaktif Tutorial, yaitu dilakukan di kelas XI IPS 2 yang berjumlah 33 siswa. Tenaga pengajar yang diterapkan untuk melakukan pembelajaran menggunakan multimedia pembelajaran interaktif Powerpoint diberikan pedoman treatment strategi pembelajaran mengenai cara penyajian materi pembelajaran.

Penelitian menggunakan metode eksperimen dangan rancangan quasi eksperimen. Hal ini dilakukan dalam pelaksanaan penelitian ini, kelas ini sudah terbentuk sebelumnya. Desain penelitian menggunakan faktorial 2 × 2 seperti digambar dalam Tabel 1 berikut: 
Tabel 1. Rancangan Penelitian

\begin{tabular}{|l|l|l|}
\hline Multimedia Pembelajaran Interaktif & $\begin{array}{c}\text { Drill and } \\
\text { Practice }\end{array}$ & \multicolumn{1}{|c|}{ Tutorial } \\
\hline Tinggi (B1) & $A 1 B 1$ & $A 2 B 1$ \\
\hline Rendah (B2) & $A 1 B 2$ & $A 2 B 2$ \\
\hline
\end{tabular}

Keterangan

$\mathrm{A} 1=$ Multimedia interaktif Drill and Practice

A2 = Multimedia interaktif Tutorial

B1 = Motivasi Belajar Tinggi

B2 = Motivasi Belajar Rendah

A1B1 = Hasil Belajar Teknologi Informasi dan Komunikasi (TIK) siswa yang diajar dengan multimedia Pembelajaran interaktif Drill and Practice pada siswa yang mempunyai motivasi belajar tinggi

A2B1 = Hasil Belajar Teknologi Informasi dan Komunikasi (TIK) siswa yang diajar dengan multimedia Pembelajaran interaktif Tutorial pada siswa yang mempunyai motivasi belajar tinggi

A1B2 = Hasil Belajar Teknologi Informasi dan Komunikasi (TIK) siswa yang diajar dengan multimedia Pembelajaran Drill and Practice pada siswa yang mempunyai motivasi belajar rendah

A2B1 = Hasil Belajar Teknologi Informasi dan Komunikasi (TIK) siswa yang diajar dengan multimedia Pembelajaran Tutorial pada siswa yang mempunyai motivasi belajar rendah.

Teknik analisis data yang digunakan adalah Teknik Statistik Deskriptif dan inferensial. Teknik statistik deskriptif digunakan untuk mendeskriptifkan data, antara lain: nilai rata-rata (mean), median, modus, standard deviasi (sd), variansi, dan kecenderungan data. Teknik statistik inferensial digunakan untuk menguji hipotesis penelitian, dimana teknik statistik inferensial yang digunakan tenik analisis varians (ANAVA) dua jalur (desain faktorial $2 \times 2$ ) dan uji statistik yang digunakan adalah uji $\mathrm{F}$ dengan $\alpha=0,005$.

Sebelum menggunakan teknik ini, lebih dahulu ditentukan persyaratan analisi yakni persyaratan Normalitas dan Homogenitas. Untuk uji persyaratan Normalitas menggunakan Lillefors, sedangkan uji persyaratan Homogenitas menggunakan Uji $F$ dan Uji Barlett. Dari hasil analisis data, apabila terdapat perbedaan penggunaan multimedia pembelajaran interaktif dan interaksi antara penggunaan multimedia pembelajarainteraktif dengan motivasi belajar terhadap tingkat A1 pengetahuan operasional komputer signifikan, maka dilakukan uji lanjut untuk melihat kelompok mana yang lebih signifikan perbedaannya.

Selanjutnya digunakan uji Scheffe sebab jumlah sampel setiap sel berbeda. Untuk keperluan pengujian hipotesis, diperlukan rumusan hipotesis statistik sebagai berikut:

Hipotesis Pertama : Ho : $\mu_{\mathrm{A} 1} \leq \mu_{\mathrm{A} 2}$ $\mathrm{Ha}: \mu_{\mathrm{A} 1}>\mu_{\mathrm{A} 2}$

Hipotesis Kedua : Ho : $\mu_{\mathrm{B} 1} \leq \mu_{\mathrm{B} 2}$ $\mathrm{Ha}: \mu_{\mathrm{B} 1}>\mu_{\mathrm{B} 2}$

Hipotesis Ketiga`: Ho : $\mathrm{A}$ x B $=0$ $\mathrm{Ha}: \mathrm{A} \times \mathrm{B} \neq 0$

\section{HASIL DAN PEMBAHASAN Hasil}

Untuk keperluan pengujian hipotesis dengan menggunakan teknis analisis varians dua jalur faktorial 2 x 2 dan uji lanjut Tukey diperlukan harga rata-rata tiap kelompok, berikut ini disajikan data hasil belajar Teknologi Informasi dan Komunikasi siswa pada Tabel 2.

Tabel 2. Rangkuman Hasil Perhitungan Analisis Deskriptif

\begin{tabular}{|l|l|l|l|l|}
\hline \multirow{2}{*}{ Ringkasan Data } & \multicolumn{2}{|l|}{ Penggunaan Multimedia Pembelajaran Interaktif } & \multirow{2}{*}{ Total } \\
\cline { 3 - 4 } & \multirow{3}{*}{ Tinggi } & Latihan dan Praktek & \multicolumn{1}{|c|}{ Tutorial } & \multicolumn{1}{c|}{$=37$} \\
& & $\mathrm{~N}=530$ & $\mathrm{~N}=19$ & $\mathrm{~N}=37$ \\
& & $\sum \mathrm{X}=474$ & $\sum \mathrm{X}=1004$ \\
& & $\bar{X} \mathrm{X}^{2}=15006$ & $\sum \mathrm{X}^{2}=12070$ & $\sum \mathrm{X}^{2}=27076$ \\
& $\bar{X}=27,61$ & $\bar{X}=25$ & $\bar{X}=26,38$ \\
\hline
\end{tabular}




\begin{tabular}{|c|c|c|c|c|}
\hline $\begin{array}{l}\text { Motivasi } \\
\text { Belajar }\end{array}$ & Rendah & $\begin{array}{l}\mathrm{N}=14 \\
\sum X=307 \\
\sum X^{2}=6919 \\
\bar{X}=21,78\end{array}$ & $\begin{array}{l}\mathrm{N}=14 \\
\sum X=330 \\
\sum X^{2}=7960 \\
\bar{X}=23,57\end{array}$ & $\begin{array}{l}N=28 \\
\sum X=637 \\
\sum X^{2}=14879 \\
\bar{X}=22,64\end{array}$ \\
\hline \multicolumn{2}{|c|}{ Total } & $\begin{array}{l}N \quad=32 \\
\sum X=837 \\
\sum X^{2}=21925 \\
\bar{X}=25,06\end{array}$ & $\begin{array}{l}\mathrm{N}=33 \\
\sum X=804 \\
\sum X^{2}=20030 \\
\bar{X}=24,72\end{array}$ & $\begin{array}{l}\mathrm{N}=60 \\
\sum \mathrm{X}=1641 \\
\sum \mathrm{X}^{2}=41955 \\
\bar{X}=24,75\end{array}$ \\
\hline
\end{tabular}

Setelah data Tabel 3 diolah dengan Anava 2 jalur faktorial 2 x 2, maka diperoleh hasil analisis seperti ditunjukkan pada Tabel 3.

Tabel 3. Ringkasan Perhitungan Anava faktorial 2 x 2.

\begin{tabular}{|c|c|c|c|c|c|c|}
\hline Sumber Varians & $\mathrm{dk}$ & $\mathrm{JK}$ & RJK & Fhitung & $\begin{array}{c}\mathrm{F} \text { tabel } \\
0,05\end{array}$ & ket \\
\hline Penggunaan multimedia (A) & 1 & 52,20 & 52,20 & 3,91 & 3,16 & Signifikan \\
\hline Motivasi belajar (B) & 1 & 306,48 & 306,48 & 22,97 & 3,16 & Signifikan \\
\hline Interaksi $(\mathrm{AB})$ & 1 & 153,63 & 153,63 & 11,51 & 3,16 & Signifikan \\
\hline Galat & 61 & 813,75 & 13,34 & & & \\
\hline Total & 64 & 1326,06 & & & & \\
\hline
\end{tabular}

Pada tabel ringkasan ANAVA untuk penggunaan multimedia pembelajaran interaktif diperoleh $\mathrm{F}_{\text {hitung }}=3,91>\mathrm{F}_{\text {tabel }}=3,16$, untuk motivasi belajar $\mathrm{F}_{\text {hitung }}=22,97>\mathrm{F}_{\text {tabel }}=3,16$ dan untuk interaksi $\mathrm{F}_{\text {hitung }}=11,51>\mathrm{F}_{\text {tabel }}=3,16$. Berdasarkan data-data tersebut, dapat disimpulkan adanya interaksi antara penggunaan multimedia pembelajarn interaktif dengan motivasi belajar yang mempengaruhi hasil belajar Teknologi Informasi dan Komunikasi

Pengujian dilakukan terhadap hipotesis statistik yang dirumuskan sebagai berikut:

Ho $: \mu_{\mathrm{A} 1 \mathrm{~B} 1}=\mu_{\mathrm{A} 1 \mathrm{~B} 2}$

$\mathrm{Ha}: \mu_{\mathrm{A} 1 \mathrm{~B} 1}>\mu_{\mathrm{A} 1 \mathrm{~B} 2}$

Ringkasan Anava faktorial 2 × 2 pada tabel 4. 16 menunjukkan bahwa $\mathrm{F}_{\text {hitung }}$ lebih besar dari $\mathrm{F}_{\text {tabel }}\left(\mathrm{F}_{\text {hitung }}=3,91>\mathrm{F}_{\text {tabel }}=\right.$ 3,61 ). Ini berarti Ho ditolak sebaliknya menerima Ha pada taraf signifikansi $\alpha=0,05$. Dengan demikian temuan penyimpulan, bahwa hipotesis penelitian yang menyatakan hasil belajar Teknologi Informasi dan Komunikasi siswa yang menggunakan multimedia pembelajaran interaktif latihan dan paraktik lebih tinggi dari pada siswa yang dibelajarkan dengan menggunakan multimedia pembelajaran tutorial teruji kebenaranya.

Perbedaan hasil belajar Teknologi Informasi dan Komunikasi dari siswa yang memiliki motivasi belajar tinggi dan motivasi belajar rendah dilakukan dengan analisis varians. Pengujian dilakukan terhadap hipotesis yang dirumuskan sebagai berikut:

Hipotesis yang dirumuskan berbentuk:

Ho $: \mu_{\mathrm{A} 1 \mathrm{~B} 1}=\mu_{\mathrm{A} 1 \mathrm{~B} 2}$

Ha $: \mu_{\mathrm{A} 1 \mathrm{~B} 1}>\mu_{\mathrm{A} 1 \mathrm{~B} 2}$

Ringkasan Anava faktorial 2 x 2 pada tabel 4.17 menunjukkan bahwa $F_{\text {hitung }}$ lebih besar dari $\mathrm{F}_{\text {tabel }}\left(\mathrm{F}_{\text {hitung }}=22,97>\mathrm{F}_{\text {tabel }}=\right.$ 3,16 ). Ini berarti Ho ditolak sebaliknya menerima Ha pada taraf signifikansi $\alpha=0,05$. Dengan demikian temuan penyimpulan, bahwa hipotesis penelitian yang menyatakan hasil belajar TIK siswa yang memiliki motivasi belajar tinggi lebih tinggi dari pada siswa yang memiliki motivasi belajar rendah teruji kebenarannya.

Pengujian dilakukan terhadap hipotesis statistik yang dirumuskan sebagai berikut:

Hipotesis yang dirumuskan berbentuk:

Ho : Interaksi $(\mathrm{B} \times \mathrm{T})=0$

Ha : Interaksi ( B x T ) $\neq 0$

Ringkasan Anava faktorial 2 × 2 pada Tabel 4. 17 menunjukkan bahwa $F_{\text {hitung }}$ lebih besar dari $\mathrm{F}_{\text {tabel }}\left(\mathrm{F}_{\text {hitung }}=11,51>\mathrm{F}_{\text {tabel }}=\right.$ 3,16 ). Ini berarti Ho ditolak sebaliknya menerima Ha pada taraf signifikansi $\alpha=0,05$. Dengan demikian hipotesis penelitian yang menyatakan terdapat interaksi antara MPI dan motivasi belajar dalam mempengaruhi hasil belajar TIK teruji kebenarannya.

Sehubungan dengan adanya interaksi maka perlu dilakukan uji lanjut dengan uji 
Tukey. Uji lanjut dengan uji Tukey dikarenakan bayak data untuk setiap sel adalah sama, hasil pengujian dengan menggunakan uji Tukey dapat dilihat pada Tabel 4. berikut:

Tabel 4. Ringkasan Hasil Pengujian dengan Menggunakan Uji Tukey

\begin{tabular}{|r|l|l|r|c|}
\hline No & \multicolumn{2}{|c|}{ Hasil Uji Lanjut } & Fhitung & $\begin{array}{l}\text { Ftabel } \\
(0,05)\end{array}$ \\
\hline 1 & $\mathrm{FA}_{1} \mathrm{~B}_{1}$ & $\mathrm{FA}_{2} \mathrm{~B}_{1}$ & 14,74 & 2,76 \\
\hline 2 & $\mathrm{FA}_{1} \mathrm{~B}_{1}$ & $\mathrm{FA}_{1} \mathrm{~B}_{2}$ & 21,50 & 2,76 \\
\hline 3 & $\mathrm{FA}_{1} \mathrm{~B}_{1}$ & $\mathrm{FA}_{2} \mathrm{~B}_{2}$ & 10,33 & 2,76 \\
\hline 4 & $\mathrm{FA}_{2} \mathrm{~B}_{1}$ & $\mathrm{FA}_{1} \mathrm{~B}_{2}$ & 6,68 & 2,76 \\
\hline
\end{tabular}

\begin{tabular}{|l|l|l|l|l|}
5 & $\mathrm{FA}_{2} \mathrm{~B}_{1}$ & $\mathrm{FA}_{2} \mathrm{~B}_{2}$ & 1,31 & 2,76 \\
\hline 6 & $\mathrm{FA}_{1} \mathrm{~B}_{2}$ & $\mathrm{FA}_{2} \mathrm{~B}_{2}$ & 2,80 & 2,76 \\
\hline
\end{tabular}

Hasil pengujian hipotesis di atas, menunujukkkan adanya interaksi anatara siswa yang dibelajarkan menggunakan multimedia interaktif dan motivasi belajar terhadap hasil belajar Teknologi Informasi dan Komunikasi. Interaksi antara pembelajaran menggunakan multimedia interaktif dengan motivasi belajar tersebut dapat divisualisasikan delam grafis pada Gambar 1.

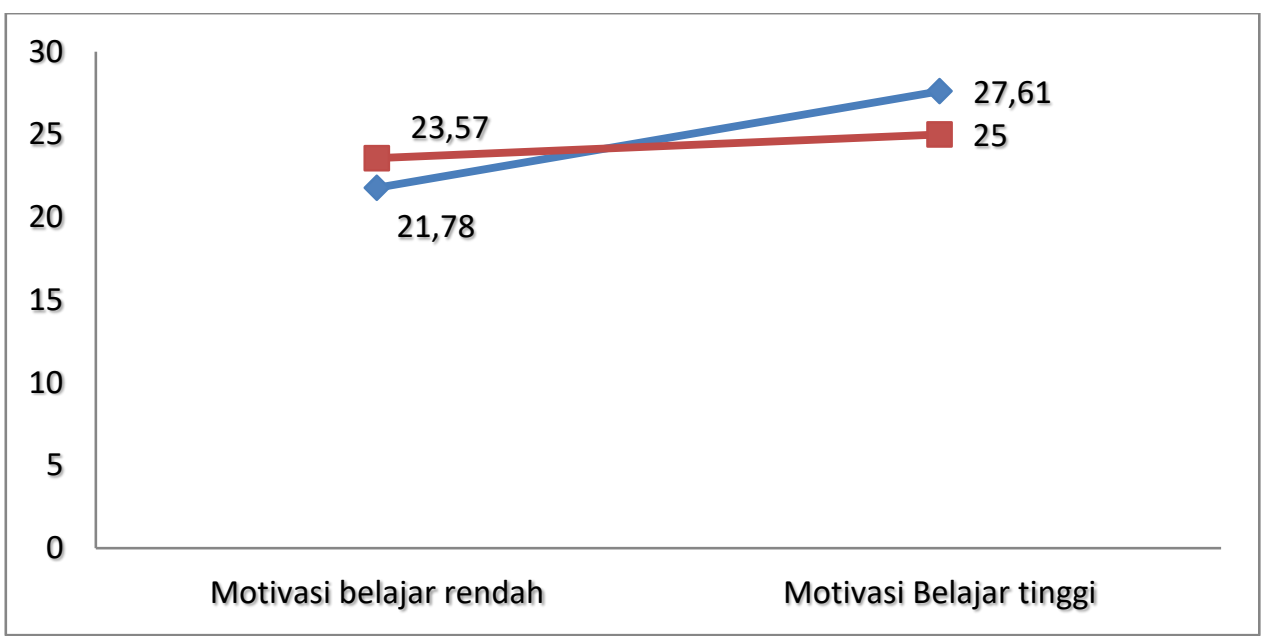

Gambar 1. Interaksi Multimedia Pembelajaran Interaktif dan Motivasi Belajar Terhadap hasil Belajar Teknologi Informasi dan Komunikasi

ketiga menyatakan adanya interaksi penggunaan multimedia pembelajaran interaktif dengan motivasi belajar, maka perlu dilakukan uji perbedaan rata-rata anatar dua proporsi. Gambar 1 menunjukkan pengaruh dan interaksu daripenggunaan multimedia pembelajaran dan motivasi belajar terhadap hasil belajar Teknologi Informasi dan Komunikasi yang diperolah siswa, rata-rata hasil belajar Teknologi Informasi dan Komunikasi siswa yang dibelajarkan dengan menggunakan multimedia interaktif dan praktik lebih tinggi dibandingkan rata-rata hasil belajar siswa dengan menggunakan multimediapembelajaran interaktif tutorial. Pada penelitian ini juga membuktikan faktor motivasi belajar siswa sebagai salah satu karakteristik siswa yang perlu menjadi perhatian karena membuktikan bahwa motivasi belajar berpengaruh terhadap hasil belajar Teknologi Informasi dan Komunikasi.

\section{Pembahasan}

Berdasarkan pengolahan data yang diperoleh bahwa terdapat perbedaan hasil belajar Teknologi Informasi dan Komunikasi antara siswa yang dibelajarkan dengan multimedia pembelajaran interaktif latihan dan praktik dengan multimedia pembelajaran tutorial, dimana nilai rata-rata Teknologi Informasi dan Komunikasi yang dibelajarkan dengan menggunakan multimedia pembelajaran interaktif latihan dan praktik lebih tinggi daripada hasil belajar siswa yang diajarkan dengan menggunakan multimedia pembelajaran tutorial. Dengan demikian mengajarkan materi Teknologi Informasi dan Komunikasi akan lebih baik menggunakan multimedia pembelajaran interaktif latihan dan praktik 
dibandingkan dengan menggunakan multimedia pembelajaran tutorial.

latihan $\begin{gathered}\text { Multimedia } \\ \text { dan }\end{gathered} \quad \begin{gathered}\text { pembelajaran interaktif } \\ \text { praktik merupakan }\end{gathered}$ pembelajarandengan jalan melatih siswa terhadap bahan pelajaran yang sudah diberikan. Metode dalam pembelajaran ini menanamkan kebiasaan tertentu dalam bentuk latihan. Dengan demikian latihan yang terus menerus diharapkan akan tertanam kebiasaan, kecepatan, ketepatan, kesempurnaan dalam melakukan sesuatu, serta dapat pula dipakai sebagai suatu cara mengulangi bahan latihan yang telah disajikan, juga dapat menambah keceapatan. ( Rusman, 2009:283).

Pada multimedia pembelajaran interaktif ini, latihan yang diberikan guru dimaksudkan untuk melatih keterampilan siswa dalam menggunakan komputer terutama dalam pelaksaan pembelajaran dilakukan.

Dalam pembelajan Teknologi Informasi dan Komunikasi, Microsoft Excel dengan menggunakan Microsoft Powerpoint pada multimedia pembelajaran interaktif latihan dan praktik siswa lebih banyak melakukan latihan terhadap bahan pelajaran yang sudah diberikan. Multimedia pembelajaran menanamkan kebiasaan tertentu dalam bentuk latihan. Dengan latihan yang terus menerus diharapkan akan tertanam kebiasaan, kecepatan, ketepatan, kesempurnaan dalam melakukan sesuatu, serta dapat pula dipakai sebagai suatu cara mengulangi bahan latihan yang telah disajikan, juga dapat menambah keceapatan. (Rusman, 2009:283). Pada multimedia pembelajaran interaktif latihan dan praktikini latihan yang diberikan guru yang dimaksud untuk melatih keterampilan siswa dalam menggunakan komputer terutama dalam pelaksanaan pembelajaran yang dilakukan

Dari penelitian ini diperoleh rata-rata hasil belajar Teknologi Informasi dan Komunikasi siswa yang dibelajarkan dengan menggunakan media pembelajaran interaktif latihan dan praktik lebih tinggi daripada hasil belajar Teknologi Informasi dan Komunikasi siswa yang dibelajarkan dengan multimedia pembelajaran tutorial, meskipun hasil belajar rata-rata siswa antara kedua kelompok tidak terlalu jauh berbeda. Dengan demikian hasil penelitian yang ditemukan sesuai dengan pendapat yang dikemukakan Sadiman (2003) bahwa multimedia pembelajaran mendukung kegiatan belajar, dimana fungsi atau kegunaan media anatara lain: (a) membuat konkrit konsep yang abstrak, (b) membawa obyek yang berbahaya atau sukar didapat ke dalam lingkungan belajar, (c) menampilkan objek yang terlalu besar, (d) menampilakn objek yang tidaka dapat diamati dengan mata telanjang, (e) mengamati gerakan yang terlalu cepat, (f) memungkinkan siswa berinteraksi langsung dengan lingkungan, (g) memungkinkan kesegaran pengamatan dan persepsi bagi pengamatan belajar siswa, (h) membangkitkan motivasi belajar, (i) menyajikan informasi belajar secara konsisten dan dapat diulangi maupun disimpan menurut kebutuhan, (j) menyajikan pesan atau informasi belajar secar serempak, membatasi batasan waktu maupun ruang, dan (k) mengontrol arah maupun kecepatan belajar siswa. Pemilihan media yang tepat dalam pembelajaran akan membuat siswa semakin memahami dan mendalami isi materi pembelajaran dan berperan aktif untuk mencari dan mengali materi sehingga dapat meningkatkan hasil belajar TIK siswa.

Temuan peneliti ini mendukung penelitian sebelumnya yang dilakukan oleh Tarigan (2011) "Pengaruh Model Pembelajaran dan Tingkat Pengetahuan Komputer Terhadap Hasil Belajar Teknologi Informasi dan Komunikasi Siswa Sekolah Menengah Atas (SMA) Negeri Kecamatan Sunggal" Hasil belajar Teknologi Informasi dan Komunikasi siswa yang memiliki tingkat pengetahuan komputer rendah bila diajarkan dengan model pembelajaran advante organizer lebih baik dari pada menggunakan model pembelajaran blended. Penelitian sejenis juga yang dilakukan oleh Putra (2008) pada siswa MTs yang menunjukkan bahwa penggunaan multimedia interalktif berbasis komputer lebih efektif dalam meningkatkan pengetahuan dan pemahaman siswa dibandingkan dengan menggunakan media konvensional pada mata pelajaran Teknologi Informasi dan Komunikasi.

Hasil penelitian menunjukkan bahwa rata-rata hasil belajar Teknologi Informasi dan Komunikasi siswa yang memiliki motivasi belajar tinggi dibandingkan hasil belajar TIK siswa yang memiliki motivasi belajar rendah. Selanjutnya dalam penelitian ini juga terbukti bahwa hasil belajar Teknologi Informasi dan Komunikasi siswa yang memiliki motivasi belajar tinggi yang dibelajarkan dengan menggunakan mutimedia pembelajaran interaktif tutorial lebih tinggi daripada hasil belajar Teknologi Informasi dan Komunikasi siswa yang memiliki motivasi belajar rendah 
dibandingkan dengan menggunakan multimedia pembelajaran interaktif latihan dan praktik. Hal ini berindikasi bahwa siswa yang memiliki motivasi belajar tinggi lebih mampu memahami materi pelajaran Teknologi Informasi dan Komunikasi dibandingkan dengan siswa yang memiliki motivasi belajar rendah.

Motivasi belajar merupakan serangkaian usaha untuk menyediakan kondisikondisi tertentu, dorongan (tenaga) atau faktor yang dapat membangkitkan, mempengaruhi, menimbulkan, mengarahkan, dan mengorganisasikan serta memelihara tingkah laku manusia yang berhubungan dengan lingkungan belajar dalam memenuhi cita-cita, aspirasi siswa, semangat belajar yang akan membuat kepuasan siswa dengan memberikan angka, hadiah, ulangan, hasil belajar serta pujian yang mempengaruhi siswa dalam meningkatkan kemauan dan semangat belajar dalam mencapai tujuan pembelajaran.

Menurut Riduan, (2005: 201) motivasi dipandang berperan dalam belajar karena motivasi mengandung nilai nilai yaitu: (1) motivasi menentukan tingkatan berhasil atau gagalnya kegiatan siswa belajar, belajar tanpa motivasi sulit untuk mencapai keberhasilan dalam mencapai keberhasilan secara optimal, (2) pembelajaran yang bermotivasi pada hakekatnya adalah pembelajaran yang sesuai dengan kebutuhan, dorongan, motif, minat yang ada pada diri siswa. (3) pembelajaran yang bermotivasi menurut kreatifitas dan imajinasi guru untuk berupaya secara sungguh-sungguh mencari cara-cara yang relevan dan serasi guna membangkitkan dan memelihara motivasi belajar siswa. (4) berhasil atau gagalnya dalam membangkitkan dan mendayagunakan motivasi dalam proses pembelajaran berkaitan dengan upaya pembinaan disiplin kelas, (5) penggunaan azas motivasi merupakan sesuatu yang esensial dalam proses belajar dan pembelajaran, motivasi menjadi salah satu faktor yang turut menentukan pembelajaran yang efektif. Karena motivasi belajar mampu dorongan dalam peningkatan hasil belajar siswa.

Dengan segala kemampuan yang dimilikinya siswa yang memiliki motivasi belajar tinggi akan mudah mencapai berbagai berbagai kompetensi dasar pada mata pelajaran Teknologi Informasi dan Komunikasi dibanding dengan siswa yang memiliki motivasi belajar rendah.
Pada penelitian ini juga dapat dibuktikan bahwa pembelajaran yang dibelajarkan dengan menggunakan multimedia interaktif latihan dan praktik mampu meningkatkan kompetensi siswa dalam pelajaran Teknologi Informasi dan Komunikasi. Ketika pembelajaran Teknologi Informasi dan Komunikasi diberikan dengan menggunakan multimedia interaktif latihan dan praktik kepada siswa yang memiliki motivasi belajar negatif akan lebih mudah dipahami karna siswa akan melakukan latihan-latihan yang berulang secara langsung setelah dibimbing oleh guru. Siswa ayang memiliki motivasi harus mendapatkan penjelasan dari guru sebagai narasumber utama dalam memahami setiap materi yang diberikan karena siswa perlu melakukan latihan-latihan secara langsung setelah diberikan pembelajaran.

Hasil belajar Teknologi Informasi dan Komunikasi siswa SMA Negeri 1 Sunggal dipengaruhi oleh multimedia pembelajaran interaktif berbasis komputer dan motivasi belajar siswa. multimedia pembelajaran interaktif latihan dan praktik memberi pengaruh yang lebih tinggi dibanding dengan hasil belajar dengan menggunakan multimedia pembelajaran interaktif tutorial. Dengan berdasarkan hasil temuan penelitian dan hasil uji perbandingan ganda dengan uji Tukey, serta beberapa penelitian yang relevan, maka dapat disimpulkan bahwa, pertama: hasil belajar Teknologi Informasi dan Komunikasi siswa yang menggunakan multimedia pembelajaran interaktif latihan dan praktik lebih tinggi dibanding dengan menggunakan multimedia pembelajaran interaktif tutorial hal ini dapat dijelaskan jalannya pembelajaran serta faktor penyebabnya yaitu: : (a) menjelaskan terlebih dahulu tujuan atau kompetensi; (b) menentukan dan menjelaskan kebiasaan, ucapan, kecekatan, gerak tertentu dan sebagainya yang akan dilatihkan sehingga siswa mengetahui dengan jelas apa yang harus mereka kerjakan; (c) memusatkan perhatian siswa terhadap bahan yang akan atau sedang dilatihkan; (d) adanya selingan latihan; (e) memperhatian kesalahankesalahan yang dilakukan siswa, serta mendiagnosis kesulitan-kesulitan yang dialami oleh siswa; dan (f) latihan tidak boleh terlalu lama atau terlalu cepat. Kedua, hasil belajar Teknologi Informasi dan Komunikasi siswa yang memiliki motivasi belajar tinggi lebih baik dibanding dengan siswa yang memiliki motivasi belajar rendah, hal ini sesuai dengan karakteristik siswa yang memiliki motivasi 
belajar tinggi cenderung lebih mudah mengikuti cara belajar yang baru.

Temuan penelitian menunjukkan bahwa terdapat interaksi antara penggunaan multimedia pembelajaran interaktif berbasis komputer dan motivasi belajar siswa terhadap hasil belajar Teknologi Informasi dan Komunikasi siswa. Siswa yang memiliki motivasi belajar tinggi dengan menggunakan multimedia pembelajaran interaktif tutorial lebih tinggi hasil belajarnya dibanding dengan siswa yang memiliki motivasi belajar rendah dengan menggunakan multimedia pembelajaran interaktif yang sama. Demikian pula siswa yang memiliki motivasi belajar tinggi dengan menggunakan multimedia pembelajaran interaktif latihan dan praktik diperoleh hasil belajar yang lebih tinggi dibanding dengan siswa yang memiliki motivasi belajar rendah dengan menggunakan multimedia pembelajaran interaktif yang sama. Hal ini mengidentifikasikan adanya interaksi antara penggunaan multimedia pembelajaran interaktif berbasis komputer dengan motivasi belajar siswa terhadap hail belajar Teknologi Informasi dan Komunikasi

Mata pelajaran Teknologi Informasi dan Komunikasi meruapakan mata pelajaran yang mengharuskan siswa memiliki sejumlah kompetensi khususnya dalam bidang keterampilan komputer. Kemampuan ini akan lebih mudah diperoleh siswa yang memiliki motivasi belajar tinggi untuk mudah memahami dan berani mencoba untuk berkreasi dan menangkap isi materi yang dibelajarkan dengan menggunakan multimedia pembelajaran interaktif berbasis komputer. Siswa yang memiliki motivasi belajar tinggi akan lebih cepat menangkap isimateri yang disajikan dengan cara belajar mandiri. Motivasi belajar akan lebih berkembang jika siswa mampu secara aktif memotivasi diri secara baik dalam melaksanakan kegiatan pembelajaran sesuai dengan penyajian materi melalui multimedia pembelajaran interaktif berbasis komputer. Praktek langsung akan semakin meningkatkan hasil belajar Teknologi Informasi dan Komunikasi siswa yang memiliki motivasi Berdasarkan hasil penelitian dan pembahasan yang dikemukakan sebelumnya maka dapat disimpulkan bahwa:

1. Hasil belajar Teknologi Informasi dan Komunikasi siswa yang dibelajarkan dengan menggunakan multimedia interaktif latihan dan praktik lebih tinggi dibandingkan belajar tinggi. Selain itu siswa juga akan aktif mengikuti petunjuk atau prosedur yang dimunculkan melalui $\mathrm{Cd}$ interaktif tersebut sehingga akan merangsang siswa untuk bergerak terus mengikuti langkah-langkah yang ada didalam sajian tutorial.

Bagi siswa yang memiliki motivasi belajar rendah, pembelajaran Teknologi Informasi dan Komunikasi akan lebih baik dibelajarkan dengan menggunakan multimedia pembelajaran interaktif latihan dan praktik dibanding dengan multimedia pembelajaran interaktif tutorial. Hal ini disebabkan akan lebih mudah bagi siswa yang memiliki motivasi belajar rendah untuk memahami materi dengan cara melakukan pengulangan dengan latihanlatihan yang berulang pada materi yang diberikan. Dalam multimedia pembelajaran interaktif dapat pula dipakai sebagai suatu cara mengulangi bahan latihan yang disajikan, juga dapat menambah kecepatan. Siswa yang memiliki motivasi belajar rendah pada umumnya kurang mau untuk mencoba metode pembelajaran yang baru dan bisanya mereka akan lebih nyman dengan cara belajar yang konvensional.

Meskipun multimedia pembelajaran interaktif tutorial lebih baik digunakan bagi siswa yang memiliki motivasi belajar tinggi, namun tidak tertutup kemungkinan dapat juga dipakai oleh siswa yang memiliki motivasi belajar rendah. Hal ini dikarenakan melalui multimedia pembelajaran interaktif tutorial siswa dapat mengikuti langkah demi langkah materi pembelajaran secara langsung oleh siswa dan secara langsung dapat dipraktekkkan oleh siswa itu sendiri. Dan hasil penelitian ini juga dapat menunjukkan bahwa hasil belajar Teknologi Informasi dan Komunikasi siswa yang menggunakan multimedia pembelajaran interaktif latihan dan praktik dan multimedia pembelajaran interaktif tutorial dengan siswa yang memiliki motivasi belajar tinggi tidak terlalu jauh berbeda, artinya siswa yang memiliki motivasi belajar tinggi dapat menggunakan kedua media tersebut.

\section{PENUTUP}

dengan hasil belajar Teknologi Informasi dan Komunikasi siswa yang dibelajarkan dengan menggunakan multimedia interaktif tutorial

2. Hasil belajar Teknologi Informasi dan Komunikasi siswa yang memiliki motivasi belajar tinggi lebih tinggi daripada hasil 
belajar Teknologi Informasi dan Komunikasi siswa yang memiliki motivasi belajar rendah

3. Terdapat interaksi antara multimedia interaktif berbasis komputer dalam pembelajaran dengan motivasi belajar terhadap hasil belajar

Berdasarkan uji lanjut diperoleh hasil bahwa siswa yang memiliki motiavsi belajar tinggi lebih tinggi hasil belajar Teknologi Informasi dan Komunikasi dengan menggunakan multimedia interaktif latihan dan praktik dibandingkan dengan menggunakan multimedia interaktif tutorial dan hasil belajar siswa yang memiliki motivasi belajar rendah yang diajarkan dengan menggunakan latihan dan praktik lebih tinggi dibanding dengan siswa yang memiliki motivasi belajar rendah yang dibelajarkan dengan menggunakan multimedia interaktif tutorial.

Berdasarkan simpulan dan implikasi seperti yang telah dikemukakan, maka disarankan beberapa hal berikut ini:

1. Tujuan pemebelajaran mata pelajaran Teknologi Informasi dan Komunikasi dengan materi Microsoft Excel adalah agar siswa berkompeten dalam membuat dokumen menggunakan lembar kerja, oleh karena itu pada saat pembelajaran siswa diharapkan untuk mampu memahami materi yang diberikan dengan menggunakan multimedia interaktif. Pembelajaran menggunakan multimedia juga diharapkan didalam diri siswa sendiri memiliki motivasi belajar, kemauan dan kemampuan dalam menggunakan dan memanfaatkan teknologi yang ada. Oleh karena itu disarankan kepada guru mata pelajaran Teknologi Informasi dan Komunikasi agar menggunakan multimedia interaktif latihan dan praktik.

2. Untuk meningkatkan hasil belajar Teknologi Informasi dan Komunikasi siswa yang memiliki motivasi belajar tinggi, disarankan untuk menggunakan multimedia interaktif berbasis komputer latihan dan praktik kerena sesuai dengan karakteristik siswa tersebut. Dengan menggunakan multimedia siswa akan lebih lagi terlatih dan terbiasa untuk melakukan kegiatan dengan melakukan banyak latihan dan menjawab soal-soal yang dipertanyakan serta siswa lebih mampu mempraktikkkan. Meskipun menggunakan multimedia interaktif latihan dan praktik lebih cocok dengan siswa memiliki motivasi belajar tinggi, namun disarankan kepada guru untuk memanfaatkan multimedia ini juga kepada siswa yang memiliki motivasi rendah, karena dengan melakukan pembelajaran ini siswa akan terus menerus melakukan latihan dan praktik. Dan juga tidak tertutup kemungkinan siswa juga dapat menggunakan multimedia pembelajaran interaktif latihan dan praktik dalam pembelajaran Teknologi Informasi dan Komunikasi.

3. Pemakai multimedia pembelajaran yang sesuai dengan karakteristik siswa dan karakteristik mata pelajaran sangat mempengaruhi hasil belajar siswa. Maka itu disarankan kepada guru mata pelajaran Teknologi Informasi dan Komunikasi untuk mampu merancang atau mengembangkan multimedia pembelajaran yang berkaitan dengan mata pelajaran Teknologi Informasi dan Komunikasi. Disarankan kepada guruguru untuk lebih aktif dan kreatif dalam memilih berbagai media pembelajaran pembelajaran yang variatif dalam menyampaikan materi pelajaran, sehingga media-media pembelajaran yang digunakan dapat disesuaikan dengan karakteristik siswa dan mata pelajaran itu sendiri. Penggunaan multimedia pembelajaran interaktif latihan $\&$ praktik serta tutorial pada penelitian ini dapat dijadikan sebagai salah satu alternatif bagi guru untuk menyampaikan pembelajaran kepada siswa SMA

4. Sekolah disarankan untuk dapat menyediakan sarana multimedia pembelajaran yang lebih baik lagi untuk peningkatan kualitas pembelajaran Teknologi Informasi dan Komunikasi. Guruguru perlu dibekali dengan kemampuan untuk memafaatkan teknologi yang ada dalam memberikan pembelajaran, yaitu dengan memberikan pelatihan atau sosialisasi pemakaian multimedia

5. Pada penelitaian ini, peneliti tidak menggunakan populasi dan sampel yang besar, disarankan untuk peneliti berikutnya supaya dapat menggunakan populasi dan sampel yang lebih besar lagi. Dengan semakin besar anggota sampel yang digunakan akan semakin mengecilkan tingkat kesalahan dan meningkatkan tingkat ketelitian/kepercayaan hasil dari penelitaian

Dalam membelajarkan siswa mengunakan multimedia, guru diharapkan dapat memilih multimedia yang paling efektif dan tepat. Supaya siswa dapat beradaptasi 
dengan multimedia yang dipakai, guru wajib untuk memberikan penjelasan secukupnya kepada siswa cara-cara pemakaian dari multimedia itu sendiri. Hal ini dilakukan supaya siswa tidak canggung ataupun timbul penolakan dengan metode belajar yang berbeda.

\section{DAFTAR PUSTAKA}

Anderson, C. 2001. Taxanomy of Education Objectives. New York: Logman

Arikunto, S. 2002. Dasar-dasar Evaluasi Pendidikan. Jakarta: Bumi Aksara

Arsyad, A 2009. Media Pembelajaran. Jakarta: Rajawali Press

Arsyad. 2013. Media Pembelajaran. Jakarta: Raja Grafindo Persada

Dale, Pintrick. 2000. Motivation in Education Theory Research and Aplication, Second Edition, New Jersey

Denim, Sudarwan. 2010. Pedagogi, Andragogi, dan Heutagogi. Bandung: Alfabeta

Departemen pendidikan Nasional. 2003. Kurikulum Teknologi Informasi dan Komunikasi (TIK). Jakarta: Departemen Pendidikan Nasional

Elcom. 2012. Memilih Memakai Merawat dan Memperbaiki Netbook. Yogyakarta: Andi

Gagne, R.M.\&Briggs, L.J. 1979. Principles of Instructional Design, Second Edition. New York: rinehart and Winston

Hidayat Rudi. 2011. Teknologi Informasi Komunikasi untuk SMA Kelas XI. Jakarta: Erlangga

Heinich, Molenda \& Russell. 1985. Instructional Media and The New Tecology of Instructional, Canada: John Wiley \& Sons, Inc

Heinich, Molenda, \& Russell. 1985. Instructional Media. New York: John Wiley \& Sons

Kautsar. 2013. Belajar Komputer Dan Internet Tanpa Kursus. Yogyakarta: Media Kom

Mayer, Richard, E. 2009. Multimedia Learning (Second Edition). United State of America: Cambridge University Press

Mayer, Richard, E. 2005. The Cambridge Handbook of Multimedia Learning. United State of America: Cambridge University Press

Miarso Yusufhadi. 2004. Menyemai Benih Teknologi Pendidikan. Jakarta: Balai Pustaka

Mujiono, Dimyati. 1999. Belajar dan Pembelajaran. Jakarta: Rhineka Cipta
Muliasa H E. 2013. Pengembangan Implementasi Kurikulum 2013. Bandung: Rosda Karya

Utama Adjie Tri. 2009. Cara Mudah dan Cepat Pengoperasian Komputer. Bandar Lampung: Bintang Indonesia Jakarta

Panjaitan Keysar.2010. Peranan Komputer Di Dalam Proses Belajar, Jurnal Teknologi Pendidikan Vol 3, No. 2. Medan: Program Studi Teknologi Pendidikan Pascasarjan UNIMED.

Pramono Andi. 2004. Presentasi Multimedia dengan Macromedia Flash. Jakarta: Andi

Permana Budi. 2004. Microsoft Office Excel 2003. Jakarta: PT Elex Media Kompetindo

Resien. 2010. Pengaruh Media Pembelajaran Interaktif Berbasis Komputer Dan Sikap Inovatif Terhadap Hasil Belajar Teknologi Informasi Dan Komunikasi (TIK) Siswa SMA Methodist Tanjung Morawa. Vol 3, No. 2. Medan: Program Studi Teknologi Pendidikan Pascasarjan UNIMED.

Richard A. Schwier \& Earl R. Misanhuk.1993. Interactive Multimedia Instruction, New Jersey

Reigeluth, C.M. 1993. Instructional-Design Theories And Models: an Overview of Their Current Status. London: Lawrence Erlbaum ssociates Publisher

Rusman. 2009. Majemen Kurikulumn. Jakarta: Rajawali Press

Romizowski, A.J. 1993. Developing Interactive Multimedia Courseware and Networks:

Sadiman, A. S, Raharjo, Haryono A, Rahardito. 2003. Media Pendidikan, Pengertian, Pengembangan dan pemanfaatannya. Jakarta: Rajawali Pres

Sadiman. 2006. Teknologi Informasi dan Komunikasi untuk SMA Kelas XI. Jakarta: Erlangga

Sardiman. 2014. Interaksi dan Motivasi Belajar Mengajar. Jakarta: Raja Grafindo Persada

Sadiman, A. S, Raharjo, Haryono. 2007. Media Pendidikan. Jakarta: Raja Grafindo Persada

Santrock, W.J. 2007. Psikologi Pendidikan. Jakarta: Kencana

Simarmata, Ruth, M. 2013. Pengaruh Strategi Pembelajaran dan Tipe Kepribadian Terhadap Hasil Belajar Ekonomi Siswa Kelas X SMA Negeri 1 Siantar. Tesis 
tidak diterbitkan. Medan: Program Pascasarjana UNIMED

Sudjana, Msc, Dr, Prof. 2005. Metoda Statistika. Bandung: Tarsito

Sudjana, N. 2009. Penilaian hasil Proses Belajar Mengajar. Bandung: Tarsito

Suparman, A. 2001. Desain Instructional (Edisi Revisi). Jakarta: Universitas Terbuka

Smaldino, Russell, Heinich, \& Molenda. 2005. Instructional Tecnology and Media for Learning. New Jersey: Pearson Education, Inc

Uno, H.B. 2010. Orientasi Baru dalam Psikologi Pembelajaran. Jakarta: Bumi Aksara

Warsita, B. 2008. Teknolgi pembelajaran. Landasan dan Aplikasinya. Jakarta: Rineka Cipta 